\title{
Tracing microfossil residues of cereal processing in the archaeobotanical record: an experimental approach
}

Article

Accepted Version

Portillo, M., Llergo, Y., Ferrer, A. and Albert, R. M. (2017) Tracing microfossil residues of cereal processing in the archaeobotanical record: an experimental approach. Vegetation History and Archaeobotany, 26 (1). pp. 59-74. ISSN 0939-6314 doi: https://doi.org/10.1007/s00334-016-0571-1 Available at https://centaur.reading.ac.uk/69066/

It is advisable to refer to the publisher's version if you intend to cite from the work. See Guidance on citing.

Published version at: http://dx.doi.org/10.1007/s00334-016-0571-1

To link to this article DOI: http://dx.doi.org/10.1007/s00334-016-0571-1

Publisher: Springer

All outputs in CentAUR are protected by Intellectual Property Rights law, including copyright law. Copyright and IPR is retained by the creators or other copyright holders. Terms and conditions for use of this material are defined in the End User Agreement.

www.reading.ac.uk/centaur 
Central Archive at the University of Reading

Reading's research outputs online 


\title{
Tracing microfossil residues of cereal processing in the archaeobotanical record: an experimental approach
}

\author{
Marta Portillo ${ }^{1,2}$, Yolanda Llergo $^{3}$, AntOni Ferrer $^{4}$, Rosa M. Albert ${ }^{2,5}$ \\ 1 Department of Geography, Prehistory and Archaeology, University of the \\ Basque Country, UPV-EHU, C/ Francisco Tomás y Valiente s/n, 01006 Vitoria- \\ Gasteiz, Spain,e-mail: marta.portillo@ehu.eus
}

2 ERAAUB, Department of Prehistory, Ancient History and Archaeology, University of Barcelona, Montalegre 6-8, 08001 Barcelona, Spain

${ }^{3}$ SERP, Department of Prehistory, Ancient History and Archaeology, University of Barcelona, Montalegre 6-8, 08001 Barcelona, Spain

${ }^{4}$ Museu de Menorca, Av. Dr. Guàrdia, s/n, 07701 Maó, Menorca, Spain

${ }^{5}$ Catalan Institution for Research and Advanced Studies, ICREA, Passeig Lluís Companys 23, 08010 Barcelona, Spain

\begin{abstract}
Interdisciplinary methodological approaches are fundamental for studying tool use and crop processing patterns in the archaeological record. Many archaeological studies of plant microfossil evidence, primarily those of phytoliths, starch grains and pollen, are concerned with processing methods which can be replicated through experimentally produced plant residues. However, most of these studies rely on crop identification through the presence or absence of such microfossils while giving little or hardly any weight to taphonomy and formation processes, which are critical for interpreting archaeological contexts. An investigation of experimentally produced phytolith and pollen assemblages provides the opportunity to evaluate the impact of cereal processing on both microfossils. Controlled experiments were conducted at the Museum of Menorca, Balearic Islands, Spain, for assessing microfossil taphonomy using Iron Age Talayotic tools and Hordeum vulgare (hulled barley) grown nowadays on the island. For dehusking, a sandstone mortar and a wooden pestle were used outdoors, whereas grinding took place indoors using a limestone quern and handstone. The results indicate that the size of multicellular or anatomically connected phytoliths decreases as a result of mechanical degradation suffered through processing activities, whereas the proportion of cereal pollen grains increases through these processes. Additionally, experimental samples from dehusking and sieving provided abundant evidence of floral bracts, and also of other plant parts and even different plant species, such as phytoliths
\end{abstract}


from leaves and stems and non cereal pollen taxa, which were also to be found on the surfaces of the ground stone tools. These findings highlight the importance of integrating different lines of microfossil evidence and taking into account formation and taphonomic aspects, as well as the value of experimentally produced data for a better understanding of tool use and crop processing.

Keywords Talayotic culture - Grinding tools - Cereal processing · Phytoliths . Pollen $\cdot$ Experimental archaeology

\section{Introduction}

Ground stone artefacts and food-processing installations are present at many late Pleistocene and early Holocene sites, and tend to become more common and varied with the development of semi-sedentary communities (Bar-Yosef 1980; Dubreuil 2004; Eitam 2009; Kuijt and Finlayson 2009; Piperno et al. 2004; Willcox and Stordeur 2012; Wright 1991, 1994). Although ground stone tools have been less extensively studied than other artefacts such as pottery or chipped stone implements, they are critical for indicating changes in the use of material culture and technology. These implements have a fundamental role in many key areas of study, including intensification of plant exploitation, domestication processes and transition to early agriculture, the developments of social organization, increasing population, settlement size and sedentism, and the emergence of symbolic behaviours (Hodder 2012).

Typological and technological studies of ground stone tools such as mortars, pestles, grinding slabs, querns and handstones have traditionally played a major role regarding the characterization of these implements. However the identification of their function, the manner in which they were used and the nature of material/s processed cannot be denied as being of fundamental importance. Many functional studies have focused mainly on tracing patterns of wear from use and/or retrieving microfossil evidence from ground stone tools, primarily phytoliths and starch grains (Perry 2004; Piperno et al. 2004; Radomski and Neumann 2011). We would like to emphasize that multi-proxi archaeobotanical studies have proved to be critical (Denham et al. 2003; Emery-Barbier 2014; Kadowaki et al. 2015; Pearsall et al. 2004; Piperno et al. 2009). Such integrated studies both complement and supplement other sources of data since they are influenced by different taphonomic processes. For example, at the early Neolithic 
site of Ayn Abū Nukhayla in southern Jordan, where macrobotanical remains were not preserved, direct microfossil evidence from emmer wheat phytoliths, Cerealia pollen type and corroded grain starches was associated with in situ grinding stones and showed the use of indoor activity areas for cereal processing (Albert and Henry 2004; Emery-Barbier 2014; Portillo and Albert 2014a; Portillo et al. 2009). Our research area has focused on a recent phytolith study of a cluster of handstones from the Talayotic site of Cornia Nou, Menorca, Balearic Islands, (Fig. 1) which were located possibly in situ in a building gallery and which were related to the processing of cereals, probably Hordeum sp. (barley). However the pollen assemblages from the nearby associated sediments did not provide evidence of cereals (Portillo et al. 2014b).

The understanding of use-wear patterns and material processed with these artefacts depends greatly on experimental research. Many experimental studies have explored functional analyses of ground stone tools used for a varied range of activities which involved different kinds of motion, such as grinding, pounding, abrasion, percussion, etc., and the use of varied types of raw materials (basalt, granite, sandstone, quartzite, etc.) and processed products (cereals, legumes, acorns, meat, fish, bones, ochre, etc.) (for a complete reference list see Dubreuil and Savage 2013 Table 1, expanded from Adams et al. 2009). It is worth noting that many plant microfossil studies, primarily of phytoliths, starch grains and pollen, are concerned with processing methods which can be replicated by experimentally produced residues. Most commonly, studies have been conducted on experimental or archaeological ground stones using different types of querns, handstones and mortars, and focusing primarily on major crops such as wheat, barley, millet and maize (Geib and Smith 2008; Harvey and Fuller 2005; Pearsall et al. 2004; Procopiou 2003; Raviele 2011). Most of these studies rely on crop identification through the presence or absence of microfossil evidence, but giving little or hardly any emphasis to taphonomy and formation processes for the interpretation of ground stone tool assemblages. Clearly, it seems evident that microfossil preservation may be dependent on a varied range of depositional and post-depositional processes. One aspect, which needs to be approached quantitatively in detail, is the impact of crop processing, and particularly the possible mechanical degradation of microfossils caused by grinding processes and the later deposition of the microfossils in archaeological contexts. 
This study explores ways in which barley phytoliths and pollen grains can contribute to the interpretation of cereal processing, taking into account taphonomic aspects. The present study builds upon previous phytolith and usewear experiments conducted with Triticum monococcum (einkorn wheat) and replica grinding stones (Bofill 2014; Portillo et al. 2013). These results showed that the size of multicellular wheat or anatomically connected phytoliths decreased as a result of dehusking and grinding. In view of these earlier observations, the research reported upon here concentrates on extending the experiments to include other kinds of direct evidence from microfossil remains, from phytoliths in addition to pollen grains, in an effort to gain a better understanding of tool use and cereal processing, using an interdisciplinary approach. For these purposes, the present study expands the experimentally produced dataset to include results from a greater number of processes such as threshing, winnowing and sieving, and with the use of Iron Age Talayotic tools (mortar, quern and handstone, Supplementary Fig. 1).

The archaeological period with which we are concerned, Talayotic society, is defined by a set of cultural traits that arose in Mallorca and Menorca during the late Bronze and Iron Age (Fig. 1; Anglada et al. 2014; Micó 2005). Talayotic communities followed economic strategies based on cereal growing and herding (Hernández-Gasch et al. 2011). The macro-botanical record is dominated by winter grown cereals, especially Hordeum vulgare (barley), and to a lesser extent Triticum dicoccum (emmer wheat) (Arnau et al. 2003; Fernández-Miranda 1991, 2010; Stika 1999). Despite the fact that ground stone tools are commonly found at Talayotic sites, few specific studies have been conducted up to date (Risch 2003). Mortars are cylindrically shaped, with diameters around $40 \mathrm{~cm}$ and usually made of Miocene calcarenite. Handstones (the upper part) are generally large (average of $50 \mathrm{~cm}$ ) and querns (the lower part, some reaching $80 \mathrm{~cm}$ in length) are usually made of sandstone, conglomerate or Triassic microconglomerates (Supplementary Fig. 1). Handstones and mortars have often been found in Menorcan contexts from the second Iron Age, both inside domestic spaces as well as in open areas linked to these spaces (Ferrer et al. 2011; Hernández-Gasch et al. 2011). Based on ethnographic parallels (Ferchiou 1979; Harlan 1967; Hillman 1981, 1984), the common archaeological interpretation is that they were used for grain processing, although this would need to be confirmed by further archaeobotanical research. 
This study consists of various experimental stages based on the processes between the harvesting and storage of cereals until their grinding into flour. These experiments used hulled Hordeum vulgare (barley), a major cereal that is common in Iron Age macro-botanical datasets and which is cultivated in Menorca up to the present day. First of all we present the archaeological ground stone tools and plant material used, as well as operations related to cereal processing. We then explore the different steps of processing and their resulting products and by-products, and finally examine the microfossil assemblages obtained from a selection of products and by-products, with particular interest in the remains adhering to the working surfaces of the tools. These experimentally produced data may provide a reference framework for a better understanding of plant processing activities in the archaeological record. To conclude, we contrast and compare our results with previous experimental studies in addition to ethnoarchaeological research, primarily from the Mediterranean region, and then discuss the implications for the interpretation of prehistoric and protohistoric ground stone tool assemblages.

\section{Materials and methods}

\section{Experimental ground stone tools and plant materials}

Cereal dehusking was conducted with a replica pine wood pestle and a Talayotic stone mortar (Supplementary Fig. 1a, b). The use of wooden pestles is ethnographically attested and their effectiveness has been also ascertained experimentally (Hillman 1981; Wright 1991). The pestle was a wooden rod measuring $8 \mathrm{~cm}$ in diameter and $1 \mathrm{~m}$ length. The mortar was made of local limestone and had a cylindrical shape. Its diameter was about $40 \mathrm{~cm}$ and its depth around $20 \mathrm{~cm}$. Cereal grinding was then carried out with a Talayotic ground stone implement consisting of a moving or active upper part (handstone) made of Triassic sandstone and a passive or lower part (quern) of Triassic microconglomerate, both originating from local sources (Supplementary Fig. 1cd). The handstone had a relief shaped ridge and the bottom surface was slightly convex, measuring $55 \mathrm{~cm}$ long, $25 \mathrm{~cm}$ wide and $17 \mathrm{~cm}$ thick and weighing $23 \mathrm{~kg}$. The quern had what could be considered a circular shape, with a diameter about $77 \mathrm{~cm}$ and $25 \mathrm{~cm}$ thick. The upper surface was smooth with a slight tilt. 
The plant material used was Hordeum vulgare (hulled barley) from Algendaret Nou, in southeastern Menorca, close to Mahon and the archaeological site of Cornia Nou (Fig. 1; Supplementary Fig. 2; Anglada et al. 2012). The barley was mechanically sown in December 2010, fertilized with cow manure and harvested during the first week of June. It is important to acknowledge that we are speaking about a typical Mediterranean climate, with warm and dry summers. The annual rainfall ranges between 450 and $650 \mathrm{~mm}$, and is mostly concentrated in spring and autumn (Jansà 2004). The total rainfall registered at Mahon Airport weather station (B893) during the cereal growing season from December 2010 to June 2011 was $298.74 \mathrm{~mm}$. As for the growing area, it is located on a chromic cambisol on the Miocene platform that occupies the southern half of Menorca. This part of the island is formed of calcarenite that drains and allows rain water to easily seep through to the water table, which is close to sea level. Cambisols are suitable for crops as they have enough depth and nutrients available for optimal growth. Indeed, most Talayotic settlements are on cambisols (Gornés et al. 2004). OleoCeratonion communities characterize the local vegetation and are dominated by sclerophyllous plants. The Cyclamini-Quercetum ilicis communities tend to appear in those areas where the soils are deeper. The degradation of these communities allows the appearance of large areas with Pinus halepensis (Aleppo pine) and Pistacia lentiscus (mastic) (Bolòs 1996). According to datasets obtained by Red Balear de Aeropalinología (2015) from a Hirst-type volumetric sampler (Hirst 1952) located in Alaior-Can Salord (Fig. 1) following the protocols of REA (Galán et al. 2007; Martínez-Bracero et al. 2015), the main atmospheric pollen assemblage is dominated by Cupressaceae, Oleaceae (Fraxinus, Olea), Pinaceae, Fagaceae (Quercus) and Palmae; the most common herbaceous taxa are Amaranthaceae/Chenopodiaceae, Plantago sp., Poaceae, Parietaria sp. and Urtica sp.

At present, Hordeum vulgare, the selected cereal, is widely distributed over most of the Balearic Islands, Mallorca, Menorca, Ibiza and Formentera. In the case of hulled cereals such as barley, emmer and einkorn, the glumes or bracts (palea and lemma) are retained after threshing and winnowing. To remove these requires several operations, including dehusking and multiple sieving before grinding and processing into flour. In contrast to other free-threshing cereals such as bread or hard wheats, hulled barley with its bracts still attached to the grain (caryopsis) is 
usually a difficult cereal to process, as reported both ethnographically and experimentally (see reference list in Alonso 2014, Fig. 2b; Eitam et al. 2015).

\section{Experimental work and sampling strategies}

The main part of the experimental work was conducted at the Museum of Menorca in Mahon. Three members of the project team took part in most of the experimental processes (AF, MP and YLL). Samples for both phytolith and pollen analyses were simultaneously collected from each of the processing steps. The general descriptions of processing stages involved in the experimental work are summarized in Fig. 2 and described below.

As previously mentioned, harvesting of the barley took place during the first week of June 2011 at Algendaret Nou, in the southeastern part of the island. One of the members of the project (AF) harvested an area of $15 \mathrm{~m}^{2}$, where the mature cereal was reaped by hand using an iron sickle. Sediment samples were also obtained from the field after the harvest. The dried cereals were stored indoors at the museum until it was time for the threshing, which took place six weeks later, during the last week of July.

Only a part of the barley harvest was threshed, around $7 \mathrm{~kg}$, and this was done at the museum in an open-air courtyard. During this part of the process we tested two different ways of threshing by hand, either by rubbing the plucked ears between the hands, or by beating the whole plants against the ground and the mortar. The results from both methods were similar, with unbroken cereal grains, bracts and rachis fragments which were broken off as a result of the rubbing or beating, ear fragments and weeds. As expected, leaf and stem fragments were also noted, especially during the second process involving beating whole plants. The by-product consisted of heavy chaff. We found that both threshing processes took around 30 minutes each with three people, and therefore they proved to be effective for processing small quantities of grain.

After threshing, the products were sorted out by hand, and the grain winnowed using a $3 \mathrm{~mm}$ mesh sieve (Fig. 2b). This procedure was followed by a second sieving with a $1 \mathrm{~mm}$ mesh and accompanied by both vertical and circular movements. We were obliged to keep in mind the wind, which fortunately was moderate, and we took special care to avoid grain losses. The products resulting from the winnowing were hulled cereal grains, spikelet fragments, weed seeds, 
by-products of heavy chaff, fragments of leaves, large bract fragments and rachis. Both products and by-products obtained from threshing and winnowing were sampled and stored in plastic bags.

The grain was then placed in a limestone mortar and beaten with a wooden pestle (Fig. 2c). These processes were also conducted outdoors, in the courtyard. The movement consisted in raising the pestle and lowering it against the grain, in addition to circular movements to push the grain against the interior of the mortar. We found that the roughness and irregularities inside the mortar facilitated the task of removing the husks covering the grain. When one of us became tired, another member of the team would take her or his place. The contents of the mortar were removed and sieved on a $1 \mathrm{~mm}$ metal mesh to check whether the grain was clean and then winnowed again to ensure that the product was as clean as possible. The entire operation was repeated until the grain became clean, which took about $60 \mathrm{~min}$ in all for dehusking about $1.2 \mathrm{~kg}$ of grain. The main products resulting from these dehusking and sieving processes were complete cereal grains and weed seeds, broken naked or hulled grains and small bract fragments. The byproducts were mostly spikelet and large bract fragments from pounding, light chaff and weed remains. The samples of dehusking residues adhering to the working surfaces of the mortar were mainly small cereal and weed fragments, bract fragments and light chaff. The sampling was done in two different ways: (i) samples for pollen and phytoliths were obtained by dry brushing, (ii) by washing and brushing with distilled water for phytoliths. The main aim of multiple sampling was to assess the potential preservation of the plant microfossil assemblages adhering to the working surfaces of the tools.

Due to the large size and weight of the Talayotic quern, the grinding processes were conducted in the museum building. The process of grinding around $800 \mathrm{~g}$ took around 40 minutes. About $200 \mathrm{~g}$ of grain was placed on the central quern surface each time (Fig. 2d). The handstone (upper stone) was operated with two hands by one person, in a back and forth movement combined with a partial rotating motion. Every 10 minutes the ground products and by-products were removed. We found that having two people to work the handstone was more effective and quicker than doing it alone. Once completed, the quern (lower stone) was brushed to remove any remaining ground materials, including those from the surrounding floor surface. The grinding process resulted in a mixture of ground 
products and by-products consisted of small grain fragments, small bract fragments and flour. These were then sieved using a $0.5 \mathrm{~mm}$ metal mesh (Fig. 2e) to remove undesired particles from the flour such as husk and grain fragments, in addition to sandstone material from the grinding tools, and the samples were then weighed. The weights showed that the by-products separated by sieving represented more than half of the total ground material. The same multiple sampling strategies for microfossil analyses were used on the surfaces of the grinding stones, as described above, with dry brushing and washing with distilled water.

\section{Laboratory materials and procedures}

Table 1 lists the total number of samples that were selected for phytolith and pollen analyses. Twelve phytolith samples and ten pollen samples were collected from unprocessed whole plant material, in addition to the samples of organic material obtained from the experimental processing stages of dehusking, winnowing, sieving and grinding, and from the working surfaces of the mortar and quern. Additionally, sediment samples from soils in the field after the harvest were also examined for phytoliths. All the samples were analyzed at the laboratory of the Department of Prehistory, Ancient History and Archaeology at the University of Barcelona. Both microfossils were treated and examined following the methodology described below.

\section{Phytolith methods}

Phytolith extraction and quantitative analyses from sediment samples followed the methods of Albert et al. (1999). An accurately weighed 1g of sediment was treated with $3 \mathrm{~N} \mathrm{HCl}, 3 \mathrm{~N} \mathrm{HNO}_{3}$ and $\mathrm{H}_{2} \mathrm{O}_{2}$. Phytoliths were concentrated using 2.4 $\mathrm{g} / \mathrm{ml}$ sodium polytungstate solution, $\mathrm{Na}_{6}\left(\mathrm{H}_{2} \mathrm{~W}_{12} \mathrm{O}_{40}\right) \cdot \mathrm{H}_{2} \mathrm{O}$. Slides were mounted with $1 \mathrm{mg}$ of dried sample using Entellan New (Merck). In order to understand phytolith taphonomy as well as their differential production and accumulation in plant tissues, the whole plant and each of its parts were analyzed separately (inflorescence, stem and leaves) and cleaned by washing in an ultrasound bath with deionized water. Dried material was burnt in a muffle furnace at $500{ }^{\circ} \mathrm{C}$ for 4h and treated with $1 \mathrm{~N} \mathrm{HCl}$. Experimental samples obtained from processing residues followed the same extraction protocol. Slides were prepared and 
examined following the procedures described above, using an Olympus BX41 optical microscope. A minimum of 200 phytoliths with recognizable morphologies were counted at 400x magnification. The estimated phytolith number is based on abundances per weight of dried plant material (Table 2). The phytoliths which were unidentifiable because of dissolution are listed as weathered morphotypes. Ratios between individual (single-celled phytoliths) and multicellular structures (multi-celled or interconnected phytoliths) were also calculated. These latter data may provide information regarding the extent of silicification of plant cells as well as of preservation conditions (Albert and Weiner 2001; Albert et al. 2008; Portillo et al. 2014a). The number of individual or single cells within the multicellular phytoliths was also counted to assess differences in the range of phytolith sizes (Portillo et al. 2013). Morphological identification was based on modern plant reference collections from the Mediterranean region (Albert and Weiner 2001; Albert et al. 2008, 2011; Portillo et al. 2014a; Tsartsidou et al. 2007) and standard literature (Brown 1984; Mulholland and Rapp 1992; Piperno 1988, 2006; Rosen 1992; Twiss 1992; Twiss et al. 1969). The terms used follow the International Code for Phytolith Nomenclature (Madella et al. 2005).

\section{Pollen methods}

Samples were treated following standard pollen procedures which included treatment with $\mathrm{KOH}$, sieving at $200 \mu \mathrm{m}$, treatment with hot $\mathrm{HF}, \mathrm{HCl}$, acetolysis, and mounting in glycerine jelly (Fægri and Iversen 1989). Lycopodium clavatum spore tablets were added in order to calculate pollen concentrations (Stockmarr 1971). Pollen concentration values are expressed in number of pollen grains per gram of dry organic material (grains/g, Table 3). Pollen grains were identified and counted using a Zeiss Axioscop 40 microscope at 400× and 630× magnifications. The identification was based mainly on Fægri and Iversen (1989), Andersen (1979), Diot (1992), Reille (1992, 1995, 1998) and Beug (2004).

As with phytoliths, and in an effort to better understand the pollen retention ability of each part of the plant and the presence of pollen according to the different parts, the whole plant and each of its parts, inflorescence, stem and leaves, were analyzed separately. In addition to cereal-type, other pollen types were identified. Cereal values are expressed as a percentage of total pollen counted. 


\section{Results}

\section{Phytolith results}

Phytoliths were abundant in all the unprocessed barley samples, with over a million phytoliths/g dried material (Table 2). In contrast, the soil sample yielded much smaller amounts, as in sample PHY-1, with only 40,000 phytoliths/g sediment. The floral parts or inflorescences of the barley (PHY-3, Fig. 3a) had more phytoliths than the leaves and stems (samples PHY-4 and 5, Fig. 3b-c). This general pattern is consistent with data obtained from modern plant reference collections from the Mediterranean area that have followed a similar quantitative approach (Albert et al. 2008; Portillo et al. 2014a; Tsartsidou et al. 2007).

Phytolith abundances were also high in most of our experimental samples obtained from processing residues. The richest sample corresponded to the mortar contents derived from the dehusking processes, PHY-6, with 2.6 million phytoliths/g of material (Table 2). In contrast, samples from active tool surfaces, both the mortar and grinding stone, yielded smaller amounts, 0.12-1.3 million phytoliths/g. As previously mentioned, some of the phytoliths were not morphologically identifiable due to chemical dissolution. The dissolution index of phytoliths ranged from 2 to $15 \%$, being higher in samples from washed grinding surfaces and the final product, the sieved flour, PHY-10 and 12, with over 7\%.

The morphological results indicated that phytoliths from the floral parts dominated in all the samples (Table 4). The most common morphotypes were individual cells, mainly long cells with decorated margins, for example dendritics and echinates, with an average around $25 \%$ of all the counted morphotypes, and epidermal short cells, which are also present in leaves and stems, with an average around $8 \%$. Other characteristic morphologies were epidermal appendage hairs (awn type) and papillae. Interestingly, phytoliths from the leaves and stems were also noted, especially in samples derived from dehusking processes (Fig. 3d), including epidermal stomata cells, prickles and bulliform cells, although these latter in smaller amounts. Additionally, our results also showed that certain decorated phytolith morphotypes such as dendritic or echinate long cells were especially susceptible to mechanical degradation. As with other diagnostic phytoliths, papillae and short cells, such long cells were found fragmented and 
detached from their anatomically connected positions in multi-celled structures, and had lost their decorated margins. Multicellular phytoliths were observed in most of the samples in various proportions, from 23 to $58 \%$ of all the morphotypes (Table 2, Fig. 3e-f). The only exception was again the sample from the soil in the field PHY-1, with only $1 \%$. The ratio between individual and multicelled phytoliths ranged between 0.3 and 1.6. Multi-celled phytoliths, mainly derived from the inflorescences, were abundant in most of the samples obtained from the cereal processing. They constituted between $30-40 \%$ of all the morphotypes in most of the experimental residues, and ratios between single and multi-cells ranged from 0.3-0.7.

In order to obtain more detailed information on degradation of multicellular structures caused by cereal processing, and on phytolith taphonomy, a quantitative study of size ranges was undertaken. The range of phytolith sizes showed significant differences between the samples (Table 5). The average number of individual cells counted in multi-celled phytoliths was clearly lower in samples that had been obtained from active tool surfaces and the final product, the flour. Numbers ranged from more than 100 in non-treated inflorescences, as in sample PHY-3, to 6-22 in grinding tools and flour, as in samples PHY-8 to 12. Figure 4 shows size ranges for three selected samples, the unprocessed inflorescences, sample PHY-3, and the working surfaces of the mortar and grinding stone, samples PHY-8 and 10. It should be noted that the group of more than 100 individual or single cells within multicellular structures (> 100 cells) was only observed in the non-treated inflorescence sample, whereas the smaller size group of multicells with between 3 and 10 cells increased clearly and was dominant in samples from both tool surfaces, but especially from the grinding stone. Thus, the results indicate that the size of multicellular structures decreases as a result of the grinding process. These data are consistent with previous experimental studies conducted with Triticum monococcum (einkorn wheat) following a similar quantitative approach (Portillo et al. 2013).

\section{Pollen results}

Varying amounts of pollen grains were noted in the samples, ranging from 1,800 to 195,000 pollen grains/g dried plant material (Table 3). Cereal pollen concentrations were relatively high in most of the unprocessed barley samples, 
from 4,500-20,500 grains/g). The only exception was the sample obtained from the stem (culm), sample PO-3, with 1,000 pollen grains/g of dried material. Note that the leaves in PO-4 yielded about 20 times more pollen grains than the stems themselves in PO-2. The main concentration of cereal pollen in unprocessed barley was $79 \%$ which was observed in the leaves (Supplementary Fig. 3a).

Cereal pollen grains were also abundantly identified in most experimental processing samples. The richest sample by far was from the remains adhering to the active surface of the mortar, PO-7, with 145,000 grains/g (Table 3). In contrast, samples obtained from the grinding stone surface yielded smaller amounts, so PO-8, had 4,000 grains/g. Pollen concentrations in both products and by-products obtained through processing stages showed significant differences. Interestingly enough, the sieved flour of PO-10 showed higher cereal pollen concentrations than its corresponding by-product PO-9, with 13,000 and 1,500 grains/g, respectively.

In addition to Cerealia type, other pollen taxa were identified in all the samples in different proportions. These belonged primarily to trees and herbaceous weeds, including Pinus, Quercus, Betula, Olea, Plantago, Chenopodiaceae, Poaceae, Rumex, Cichorioideae, Asteroideae, Fabaceae and Apiaceae (Table 3). Among most of the unprocessed barley samples, around $20 \%$ or less of the total identified pollen grains corresponded to cereals, with a major proportion noted only in the inflorescences (PO-2, 35.7\%, Table 3). In our experimental samples obtained from the sieving, winnowing and grain cleaning processes (PO-5 and PO-6) around 30-34\% corresponded to Cerealia-type. Again, another interesting feature was that the active surface of the quern (PO-8) showed similar cereal percentages, around $36 \%$. In contrast, samples obtained from the mortar surface (PO-7), as well as the final grinding by-products and products (PO-9 and 10), showed the highest proportions of cereal pollen grains, more than $76 \%$.

Most of the other pollen types mentioned above which were identified in our experimental samples are consistent with the atmospheric pollen calendar from Menorca (Red Balear de Aeropalinología 2015) and with weeds that were noted in the crop field. Among these, Olea, Quercus and Poaceae showed particularly high values in the samples taken, and they may relate to high atmospheric levels of these pollen types during the months of May to June. We assume that most of these pollen grains were trapped and retained by the cereal plants during the 
growing season, especially by their leaves, and therefore to a lesser extent as a result of pollen rain during the experimental work conducted at the museum, especially during the open-air stages.

\section{Discussion}

A basic question often encountered in archaeological research is whether ground stone tools that resemble implements recorded ethnographically were indeed used for cereal processing in the past. There are ethnographic reports of a varied range of techniques for cleaning cereals and implements linked to the processing of barley, with dehusking by roasting, soaking and rubbing, pounding with wooden or stone mortars, dehusking and grinding with rotary querns or other types of tools (Alonso et al. 2014; Baudais and Lundström-Baudais 2002; El Alaoui 2003; Ferchiou 1979; Hillman 1981, 1984; Jones 1984; Parton 2011). In addition to ethnobotany, experimental studies have provided direct evidence from cereal microremains, mainly from phytoliths, starch grains and pollen (Geib and Smith 2008; Pearsall et al. 2004; Procopiou 2003; Raviele 2011). This study relates to two main issues: i) the identification of methods of processing hulled cereals deduced from phytolith and pollen datasets, and ii) taphonomy and formation processes, which are considered fundamental for interpreting archaeological contexts. These will be briefly discussed.

Our results show that concentrations of phytoliths and pollen can be used as an initial indication of cereal processing in archaeological ground tool assemblages. Cereal microfossils were abundantly identified in most of our experimental samples. Thus, the differing amounts of microremains identified in the samples are also of significance. As noted, samples derived from the sieving, winnowing and dehusking processing stages usually yielded larger amounts of phytoliths and pollen grains than the samples obtained from grinding processes. In particular, the remains from the mortar working surfaces were significantly rich in both microfossils. According to the quantitative results of these series of processes, it appears that the cleaning of hulled cereals may provide abundant direct microfossil evidence, which may be recognized in the archaeobotanical datasets.

As expected, the morphological phytolith results indicated that the floral bracts were dominant in all processing stages, although phytoliths from the leaves and stems were also present, especially in plant material derived from the sieving and 
dehusking processes. As described in the experimental work section (see "Experimental work and sampling strategies" and Fig. 2), leaf and stem fragments were also observed as a result of the rubbing or beating of whole plants. Both cleaning techniques, either by rubbing and beating the sheaves on the ground or against a stone, a piece of wood or even a large flat basket, have been recorded ethnographically in various geographical areas for the processing of hulled cereals (Baudais and Lundström-Baudais 2002; Moreno-Larrazabal et al. 2015; PeñaChocarro et al. 2009). These activities are commonly related to the processing of small quantities of spikelets. Cleaning and dehusking processes involve the use of various types of sieves, mats, baskets and other craft items made of leather, skin or plant material, for example dwarf palm baskets made of Chamaerops humilis leaves or of esparto grass leaves including Stipa tenacissima (Alonso et al. 2014; M'Handi and Anderson 2013; Peña-Chocarro et al. 2009, 2015). The presence of phytoliths from grass, sedge and/or palm leaves and stems has been reported in archaeological ground stone tool assemblages, from various regions and time periods, including Natufian bedrock mortars, or early Neolithic and Iron Age grinding stones, and these have been interpreted as the remains from cereal or tuber processing, basketry, sieving, matting or linings (Kadowaki et al. 2015; Portillo and Albert 2014a, b; Portillo et al. 2013, 2014b; Power et al. 2014: Terradas et al. 2013). The pattern observed in our experimental phytolith assemblages may reflect threshing and cleaning processes, according to the processing techniques such as beating whole plants, and items used which were metal sieves, plastic bags and mats. We suggest that this observation should be taken into account when interpreting archaeological ground stone tool assemblages.

Also remarkable is the presence of large proportions of pollen grains other than cereals in unprocessed barley and all processing stages, and also in the plant remains from the surfaces of ground tools. According to the identified taxa, belonging primarily to trees and weeds, we assume that most of this pollen was brought in on the crop. These non cereal pollen types were abundantly noted in all unprocessed plant parts, but especially in the leaves and stems. Harvested cereals may contain a variety of other pollen types apart from cereals that have become trapped on various plant parts such as leaves, stems and floral parts (Adams 1988; Geib and Smith 2008). It is clear that pollen grains found in archaeological 
contexts may have been produced, transported, deposited and degraded differentially by a varied range of natural processes in addition to human activities. Many pollen studies have concentrated on assessing the production and dispersal of the major cereal pollen grains wheat, barley, oats and millet (Bower 1992; Diot 1992; Subba Reddi and Reddi 1986; Vicent et al. 2000; Vuorela 1973). These crops have a low pollen production and dispersal, especially when compared to other wind-pollinated wild plants (Bottema 1992; Bower 1992; Heim 1970). For this reason, cereal pollen grains are generally under-represented in pollen assemblages. According to Bohrer (1972), maize pollen adheres to seeds, husks and other plant parts. In the present study we noted that barley leaves contained the largest pollen concentrations. Our experimental study shows that in addition to cereals, other pollen taxa were present through all processing stages, but especially in those derived from grain cleaning processes. The contribution from other pollen types to maize being experimentally ground has been reported in previous studies (Geib and Smith 2008). We observed that the proportion of non-cereal pollen clearly decreases through the processes, being lower in the final products and by-products obtained from the sieved flour. Interestingly, the active surface of the grinding stone also yielded significant concentrations of such other pollen types, thus indicating that other plants indirectly involved in crop processing may have entered ground tool assemblages in the archaeological record. These findings highlight the need for further experimental research in order to improve archaeological interpretations of cereal processing activities from pollen data.

Another point that emerges from this experimental study relates to phytolith taphonomy, and it particularly addresses the impact of cereal processing and the effect that it has in causing mechanical degradation of both individual cells and multi-celled phytoliths. A number of archaeobotanical studies dealing with cereal processing assemblages have highlighted the importance of understanding taphonomic and formation processes for the analysis of various types of plant material, including charred macroremains and microfossil evidence from starch grains (Antolín and Buxó 2011; Henry et al. 2009; Valamoti 2002). Phytolith preservation has been linked to depositional and post-depositional processes, also including sampling and laboratory procedures, as pointed out in recent experimental studies conducted on modern and fossil wheat phytoliths (Cabanes 
et al. 2011; Jenkins 2009; Shillito 2011). However, there are a number of as yet unknown taphonomic issues with phytolith degradation and incorporation into cereal processing residues and particularly on ground stone tool assemblages. Our results show high multicellular concentrations and large size ranges in unprocessed plant material and processing by-products, especially when compared to the residues from the tool surfaces and the final product as sieved flour. Our results are consistent with previous experiments conducted with einkorn and replica tools (Bofill 2014; Portillo et al. 2013). These confirm that the size of both hulled wheat and barley multi-celled anatomically connected phytoliths decreases as a result of dehusking and grinding activities. We conclude that the breakdown of multicellular forms is caused by mechanical degradation of phytoliths during processing activities. In addition, consideration must be given to the depositional routes and taphonomic histories, from food processing areas to secondary depositional pathways, for example the inclusion in building materials, pit fills and midden deposits. These need to be understood in order to better interpret plant remains associated with ground stone tool assemblages.

The data from our experiments has provided us with a reference framework to assess whether phytolith and pollen assemblages found in certain archaeological contexts may be the direct result of crop processing, and whether such activities took place in those places as well. Many experimental studies have demonstrated how microfossil datasets, in particular those related to ground stone tools and plant residues from them, allow a more rigorous interpretation of archaeological assemblages. Examples include maize remains from manos (handstones) and metates (grinding slabs, querns) in the New World, together with hulled wheat and barley from mortars and grinding stones from the Mediterranean region (Geib and Smith 2008; Pearsall et al. 2004; Procopiou 2003). Our method of studying experimentally produced phytolith datasets has recently been successfully applied to the study of early Neolithic and Bronze Age grinding stones from a selection of Near Eastern sites (Portillo et al. 2013). The results of the present work show that direct human activity with the crops, including harvesting, transport and storage, may be considered in addition to the processing of cereals at indoor or outdoor site areas. Nevertheless, we assume that the patterns presented here concern a limited series of experimental processing stages dealing with cereal flour production. Keeping this in mind, we therefore conclude that the patterns reported 
in this study can be applied to archaeological contexts worldwide. A varied range of processing techniques and implements devoted to the processing of cereals, as well as the resulting products and by-products for human and/or animal consumption and other uses, have been reported by ethnographical research worldwide (Alonso 2014, and references therein). In the case of hulled cereals such as emmer, einkorn and barley, a diverse and complex set of domestic processing techniques has been described ethnographically in the Mediterranean region, including roasting, rubbing, multiple sieving and dehusking or grinding with wooden or stone mortars and pestles, rotary querns or other types of querns (Alonso et al. 2014; El Alaoui 2003; Ferchiou 1979; Hillman 1981; Parton 2011; Peña-Chocarro et al. 2009). Further experimental work will deal with some processes that still need to be studied such as soaking and roasting, and also dehusking and grinding with other types of implements, both wooden and other types of stone grinding tools. Among these techniques, dehusking by roasting is one of the processes likely to generate microremain evidence in the archaeological record and such taphonomic issues still need to be addressed more systematically through further controlled experimental research.

\section{Conclusions}

In this experimental study we have dealt with general questions concerning phytolith and pollen indicators from processing hulled barley, particularly from dehusking and grinding into flour using archaeological implements, mortar, quern and handstone. Both quantitative and morphological results provide an experimentally produced reference dataset that helps to assess whether certain archaeological microfossil assemblages may be the result of cereal processing. Likewise, our experiments point out that other activity with the crops, such as harvesting, storage and threshing, may be also considered in addition to grain cleaning, dehusking and grinding of cereals. Firstly, both phytolith and pollen grain concentrations have shown that the cleaning of hulled cereals and particularly sieving and dehusking stages may provide abundant direct microfossil evidence from floral bracts, but also from other plant parts and even from different plant taxa, such as phytoliths from leaves and stems and pollen taxa other than cereal type. This is especially relevant for tracing the nature of the 
material processed as well as other kinds of plant material that may be identified in archaeological ground stone tool assemblages.

Regarding the methodology and the positive results obtained, we note the importance of studying not only samples collected from the active surfaces of ground stone tools and corresponding products and sub-products, but also from unprocessed samples of plant material prior to the experimental work. This provides a more reliable interpretation and better understanding of ground stone tool assemblages, taking into account formation pathways and taphonomic aspects. It is well established that controlled experimentally produced datasets may allow a more detailed interpretation of archaeological assemblages and therefore the patterns reported in this study can be applied to archaeological contexts worldwide. Lastly, these results have provided some general observations about the damage to phytoliths caused by processing, and particularly the breakdown of multicellular forms. The size of multi-celled anatomically connected phytoliths decreases as a result of processing activities, and more specifically dehusking and grinding. Multicellular breakdown may be dependant both on mechanical degradation suffered through processing stages, and on a varied range of depositional and post-depositional processes, including secondary depositional pathways. These need to be understood in order to better interpret archaeological contexts.

Although certain taphonomic issues still need to be addressed more systematically, these results are especially useful for tracing the taphonomy of ground stone tool assemblages. This means that there is the need to perform a full range of cereal processing experiments (soaking, roasting) and to expand to study other stone tools as well, such as other types of grinding tools and raw materials. We therefore conclude that the patterns reported in this experimental work show the value of interdisciplinary methodological approaches for studying tool use and cereal processing activities in the archaeological record.

Acknowledgments This study was made possible by support from the Museu de Menorca and Consell Insular de Menorca. The research by the first author has been funded by the Juan de la Cierva Sub-programme (Spanish Ministry of Competitiveness and Economy, MINECO (JCI2009-04217) and HAR2013-42054-P as well as the Catalan Agency for Universities and Research Grants, AGAUR (SGR2009 1418). She is part of the Prehistory Consolidated Research Team at the University of the Basque Country, UPV/EHU (IT-622-13). Thanks are due to the Algendaret farmers, who provided us with 
the barley crops used in our experiments and to Peter Hochsieder, who assisted in the harvest. We are also grateful to Laia Macià and Joaquim de Prado, who helped in the phytolith laboratory at the University of Barcelona.

\section{References}

Adams KR (1988) The ethnobotany and phenology of plants in and adjacent to two riparian habitats in Southeastern Arizona. Doctoral Thesis, University of Arizona, Tucson. University Microfilms, Ann Arbor Adams J, Delgado S, Dubreuil L, Hamon C, Plisson H, Risch R (2009) Functional analysis of macro-lithic artifacts. In: Sternke F, Eigeland L, Costa LJ (eds) Non-flint raw material use in prehistory: old prejudices and new directions. (British Archaeological Reports, British Series 1939) Archaeopress, Oxford, pp 43-66 Albert RM, Henry D (2004) Herding and agricultural activities in Ain Abu Nukhayla (Wadi Rum, Jordan). The results of phytoliths and spherulite analyses. Paléorient 30: 81-92. doi :10.3406/paleo.2004.1012 Albert RM, Weiner S (2001) Study of phytoliths in prehistoric ash layers using a quantitative approach. In: Meunier JD, Colin F (eds) Phytoliths, applications in earth sciences and human history. Balkema, Lisse, pp 251-266

Albert RM, Lavi O, Estroff L, Weiner S, Tsatskin A, Ronen A, Lev-Yadun S (1999) Mode of occupation of Tabun Cave, Mt Carmel, Israel during the Mousterian Period: A study of the sediments and phytoliths. J Archaeol Sci 26:1,249-1,260. doi:10.1006/jasc.1999.0355

Albert RM, Shahack-Gross R, Cabanes D, Gilboa A, Lev-Yadun S, Portillo M, Sharon I, Boaretto E, Weiner S (2008) Phytolith-rich layers from the late Bronze and Iron Ages at Tel Dor (Israel): mode of formation and archaeological significance. J Archaeol Sci 35:57-75. doi:10.1016/j.jas.2007.02.015

Albert RM, Esteve X, Portillo M, Rodríguez-Cintas A, Cabanes D, Esteban I, Hernández F (2011) Phytolith CoRe, phytolith reference collection. http://phytcore.org/phytolith/index. Accessed 21 March 2015

Alonso N (2014) Etnoarqueología del proceso de molienda manual de cereales: grañones, sémolas y harinas. Revista d'Arqueologia de Ponent 24:113-136

Alonso N, Cantero FJ, Jornet R, López D, Montes E, Prats G, Valenzuela S (2014) Milling wheat and barley with rotary querns: The Ouarten women (Dahmani, Kef, Tunisia). In: Selsing L (ed) Seen through a millstone. Museum of Archaeology, University of Stavanger, Stavanger, pp 11-30

Andersen ST (1979) Identification of wild grass and cereal pollen. Danmarks Geologiske Undersøgelse Årbog 1978: 69-92

Anglada M, Ferrer A, Plantalamor L, Ramis D, Van Strydonck M (2012) Arquitectura monumental y complejidad social a partir de finales del segundo milenio cal BC: el edificio sur del sector oeste de Cornia Nou (Menorca). Sardinia, Corsica et Baleares Antiqvae: International Journal of Archaeology 10:23-44

Anglada M, Ferrer A, Plantalamor L, Ramis D, Van Strydonck M, De Mulder G (2014) Chronological framework for the early Talayotic period in Menorca: the settlement of Cornia Nou. Radiocarbon 56:411-424. doi: $10.2458 / 56.16962$

Antolín F, Buxó R (2011) Proposal for the systematic description and taphonomic study of carbonized cereal grain assemblages: a case study of an early Neolithic funerary context in the cave of Can Sadurní (Begues, Barcelona province, Spain). Veget Hist Archaeobot 20:53-66. doi:10.1007/s00334-010-0255-1 
Arnau P, Gornés S, Stika HP (2003) Los hipogeos de Salblegall (Ferreries) y la agricultura cerealística a mediados del segundo milenio cal ANE en Menorca. Trabajos de Prehistoria 60:117130. doi: 10.3989/tp.2003.v60.i2.84

Bar-Yosef O (1980) Prehistory of the Levant. Ann Rev Anthropol 9:101-133. doi:10.1146/annurev.an.09.100180.000533

Baudais D, Lundström-Baudais K (2002) Enquête ethnoarchéologique dans un village du nord-ouest du Népal: les instruments de mouture et de broyage. In: Procopiou H, Treuil R (eds) Moudre et broyer. L'interprétation fonctionnelle de l'outillage de mouture et de broyage dans la préhistoire et l'antiquité. (I Méthodes). Comité des Travaux Historiques et Scientifiques, Paris, pp 155-180

Beug HJ (2004) Leitfaden der Pollenbestimmung für Mitteleuropa und angrenzende Gebiete. Pfeil, München Bofill M (2014) Inicio y consolidación de las prácticas agrícolas durante el neolítico en el Levante Mediterráneo (Septentrional y Central): El proceso de molienda y trituración a partir del estudio funcional del instrumental macrolítico. Doctoral Thesis, Universitat Autònoma de Barcelona. http://hdl.handle.net/10803/294272. Accessed 21 May 2015

Bohrer V (1972) Paleoecology of the Hay Hollow site, Arizona. Fieldiana Anthropology 63:1-30

Bolòs O (1996) La vegetació de les Illes Balears: comunitats de plantes. Institut d'Estudis Catalans, Barcelona Bottema S (1992) Cereal-type pollen in the Near East as indicators of wild or domestic crops. In: Anderson PC (ed) Préhistoire de l'agriculture: nouvelles approches expérimentales et ethnographiques. (Monographie du CRA 6) CRA, Paris, pp 95-106

Bower M (1992) Cereal pollen dispersal: a pilot study. Cambridge Archaeol J 2:236-241. doi:10.1017/S0959774300000615

Brown DA (1984) Prospects and limits of a phytolith key for grasses in the central United States. J Archaeol Sci 11:345-368. doi:10.1016/0305-4403(84)90016-5

Cabanes D, Weiner S, Shahack-Gross R (2011) Stability of phytoliths in the archaeological record: a dissolution study of modern and fossil phytoliths. J Archaeol Sci 38:2,480-2,490. doi:10.1016/j.jas.2011.05.020

Denham TP, Haberle SG, Lentfer C, Fullagar R, Field J, Therin M, Porch N, Winsborough B (2003) Origins of agriculture at Kuk swamp in the Highlands of New Guinea. Science 301:189-193. doi:10.1126/science.1085255

Diot M (1992) Études palynologiques de blés sauvages et domestiques issus de cultures expérimentales. In: Anderson PC (ed) Préhistoire de l'agriculture: nouvelles approches expérimentales et ethnographiques. (Monographies du CRA 6) CRA, Paris, pp 107-111

Dubreuil L (2004) Long-term trends in Natufian subsistence: a use-wear analysis of ground stone tools. J Archaeol Sci 31:1,613-1,629. doi:10.1016/j.jas.2004.04.003

Dubreuil L, Savage D (2013) Ground stones: a synthesis of the use-wear approach. J Archaeol Sci 48:139153. doi:10.1016/j.jas.2013.06.023

Eitam D (2009) Late Epipalaeolithic rock-cut installations and groundstone tools in the southern Levant: methodology and classification system. Paléorient 35:77-104. doi:10.2307/41496963

Eitam D, Kislev M, Karty A, Bar-Yosef O (2015) Experimental barley flour production in 12,500-year-old rock-cut mortars in southwestern Asia. PLoS ONE 10(7):e0133306. doi:10.1371/journal.pone.0133306 
El Alaoui N (2003) Meules et moulins du Sud marocaine. In: Barboff M, Sigaut F, Griffin-Kremer C, Kremer R (eds) Meules à grains. Actes du colloque international La Ferte-sous-Jouarre, 16-19 mai 2002. Editions Ibis Press, Editions de la Maison des Sciences de l'Homme, Paris, pp 51-59

Emery-Barbier A (2014) Establishing the environment, seasonality, and economy from plant micro-remains: pollen and starch. In: Henry DO, Beaver JE (eds) The sands of time: the desert Neolithic settlement at Ayn Abū Nukhayla. Bibliotheca neolithica Asiae meridionalis et occidentalis. Ex oriente, Berlin, pp 105-119

Fægri K, Iversen J (1989) (eds) Textbook of pollen analysis, 4th edn. (by Fægri K, Kaland PE, Krzywinski K) Wiley, Chichester

Ferchiou S (1979) Les femmes dans l'agriculture tunisienne. Édisud, La Calade

Fernández-Miranda M (1991) La transición hacia la cultura talayótica en Menorca. Trabajos de Prehistoria 48:37-50

Fernández-Miranda M (2010) El poblado de Torralba d'en Salort (Alaior-Menorca). Fundació Illes Balears, Palma de Mallorca

Ferrer A, Juan G, Lara C, Pons J (2011) El jaciment de Torre d'en Galmés (Alaior, Menorca). Les intervencions d'Amics del Museu de Menorca: Cercle 7. In: Gual Cerdó J (ed) III Jornades d'Arqueologia de les Illes Balears (Maó, 3-4 d'octubre, 2008). (Llibres del Patrimoni Històric i Cultural 4) Consell Insular, Menorca, pp 109-117

Galán C, Cariñanos P, Alcázar P, Domínguez-Vilches E (2007) Spanish Aerobiology Network (REA): management and quality manual. Servicio de publicaciones de la Universidad de Córdoba, Córdoba

Geib PR, Smith SJ (2008) Palynology and archaeological inference: bridging the gap between pollen washes and past behavior. J Archaeol Sci 35:2,085-2,101. doi:10.1016/j.jas.2008.01.011

Gornés JS, Gual JM, López A, De Nicolás J, Roca A (2004) L'assentament humà, des de la prehistòria fins al baix imperi. In: Fornós JJ, Obrador A, Rosselló VM (eds) Història natural del migjorn de Menorca. El Medi físic i l'influx humà. Societat d'Història Natural de les Balears, Palma de Mallorca, pp 327-350

Harlan JR (1967) A wild wheat harvest in Turkey. Archaeology 20:197-201

Harvey EL, Fuller DQ (2005) Investigating crop processing using phytolith analysis: the example of rice and millets. J Archaeol Sci 32:739-752. doi:10.1016/j.jas.2004.12.010

Heim J (1970) Les relations entre les spectres polliniques récents et la végétation actuelle en Europe Occidentale. Université de Louvain, Louvain

Henry AG, Hudson HF, Piperno DP (2009) Changes in starch grain morphologies from cooking. J Archaeol Sci 36:915-922. doi:10.1016/j.jas.2008.11.008

Hillman G (1981) Reconstructing crop husbandry practices from charred remains of crops. In: Mercer R (ed) Farming practice in British Prehistory. Edinburgh University Press, Edinburgh, pp 123-162

Hillman G (1984) Interpretation of archaeological plant remains: The application of ethnographic models from Turkey. In: Van Zeist W, Casparie WA (eds) Plants and ancient man: studies in palaeoethnobotany. Balkema, Rotterdam, pp 1-41

Hernández-Gasch J, Ramis D, Rosselló JA (2011) Economia, societat i canvi cultural a les Gimnèsies. La interpretació de les dades bioarqueològiques a les Illes Balears en el primer mil·lenni ane. Economia agropecuària i canvi social a partir de les restes bioarqueològiques. El primer mil·lenni $\mathrm{aC}$ a la Mediterrània 
occidental. In: Valenzuela-Lamas S, Padrós N, Belarte MC, Sanmartí J (eds) Actes de la V Reunió Internacional d'Arqueologia de Calafell. ArqueoMediterrània 12:123-138

Hirst JM (1952) An automatic volumetric spore trap. Ann Appl Biol 39:257-265

Hodder I (2012) Entangled: an archaeology of the relationships between humans and things. Wiley and Blackwell, Oxford

Jansà A (2004) El clima del Migjorn. In: Fornós JJ, Obrador A, Rosselló VM (eds) Història Natural del Migjorn de Menorca. El Medi físic i l'influx humà. Societat d'Història Natural de les Balears, Palma de Mallorca, pp 39-52

Jenkins E (2009) Phytolith taphonomy: a comparison of dry ashing and acid extraction on the breakdown of conjoined phytoliths formed in Triticum durum. J Archaeol Sci 36:2,402-2,407. doi:10.1016/j.jas.2009.06.028 Jones G (1984) Interpretation of archaeological plant remains: ethnographic models from Greece. In: Van Zeist W, Casparie WA (eds) Plants and ancient man: studies in palaeoethnobotany. Balkema, Rotterdam, pp 43-61

Kadowaki S, Maher L, Portillo M, Albert RM, Akashi Ch, Guliyev F, Nishiaki Y (2015) Geoarchaeological and palaeobotanical evidence for prehistoric cereal storage in the southern Caucasus: the Neolithic settlement of Göytepe (mid. 8th millennium BP). J Archaeol Sci 53:408-425. doi:10.1016/j.jas.2014.10.021

Kuijt I, Finlayson B (2009) Evidence for food storage and pre-domestication granaries 11,000 years ago in the Jordan Valley. PNAS 106:10,966-10,970. doi:10.1073/pnas.0812764106

M'Handi M, Anderson P (2013) Approche ethnoarchéologique d'outils et techniques de moisson de l'alfa (Stipa tenacissima) dans la région des Hautes Steppes en Tunisie: Premières observations et analyses. In: Anderson PC, Cheval C, Durand A (eds) Regards croisés sur les outils liés au travail des végétaux. An interdisciplinary focus on plant working tools. APDCA, Antibes, pp 75-88

Madella M, Alexandre A, Ball TB, ICPN Working Group (2005) International code for phytolith nomenclature 1.0. Ann Bot 96:253-260. doi:10.1093/aob/mci172

Martínez-Bracero M, Alcázar P, Díaz de la Guardia C, González-Minero FJ, Ruiz L, Trigo Pérez MM, Galán C (2015) Pollen calendars: a guide to common airborne pollen in Andalusia. Aerobiologia 31:549-557. doi:10.1007/s10453-015-9385-3

Micó R (2005) Cronología absoluta y periodización de la prehistoria de las Islas Baleares. BAR International Series 1373. Archaeopress, Oxford

Moreno-Larrazabal A, Teira-Brión A, Sopelana-Salcedo I, Arranz-Otaegui A, Zapata L (2015) Ethnobotany of millet cultivation in the north of the Iberian Peninsula. Veget Hist Archaeobot 24:541-554. doi:10.1007/s00334-015-0518-y

Mulholland SC, Rapp JrG (1992) A morphological clasification of grass silica-bodies. In: Rapp JrG, Mulholland SC (eds) Phytolith Systematics: Emerging Issues, Advances in Archaeological and Museum Science. Plenum Press, New York, pp 65-89

Parton H (2011) The hand-mills of Olymbos: an ethnographical study of their form, function and role in a Greek vilage. In: Williams D, Peacock D (eds) Bread for the People: The Archaeology of Mills and Milling. Proceedings of a Colloquium Held in the British School at Rome. Archaeopress, Oxford, pp 29-42

Pearsall DM, Chandler-Ezell K, Zeidler JA (2004) Maize in Ancient Ecuador: results of residue analysis of stone Tools from the Real Alto site. J Archaeol Sci 31:423-442. doi:10.1016/j.jas.2003.09.010 
Peña-Chocarro L, Zapata L, González Urquijo JE, Ibáñez JJ (2009) Einkorn (Triticum monococcum L.) cultivation in mountain communities of the western Rif (Morocco): An ethnoarchaeological project. In: Fairbairn AS, Weiss E (eds) From foragers to farmers. Papers in honour of Gordon C. Hillman. Oxbow, Oxford, pp 103-111

Peña-Chocarro L, Pérez Jordà G, Morales Mateos J, Zapata L (2015) Storage in traditional farming communities of the western Mediterranean: Ethnographic, historical and archaeological data. Environ Archaeol 20:379-389. doi:10.1179/1749631415Y.0000000004

Perry L (2004) Starch analyses reveal the relationship between tool type and function: an example from the Orinoco valley of Venezuela. J Archaeol Sci 31:1,069-1,081. doi:10.1016/j.jas.2004.01.002

Piperno DR (1988) Phytolith analysis: an archaeological and geological perspective. Academic Press, San Diego

Piperno DR (2006) Phytoliths: A comprehensive guide for archaeologists and paleoecologists. AltaMira Press, Lanham

Piperno DR, Weiss E, Holst I, Nadel D (2004) Processing of wild cereal grains in the Upper Paleolithic revealed by starch grain analysis. Nature 430:670-673. doi:10.1038/nature02734

Piperno DR, Ranere AJ, Holst I, Iriarte J, Dickau R (2009) Starch grain and phytolith evidence for early ninth millennium B.P. maize from the Central Balsas River Valley, Mexico. PNAS 106:5,019-5,024. doi:10.1073/pnas.0812525106

Portillo M, Albert RM (2014a) Early crop cultivation and caprine herding: the evidence from phytolith and fecal spherulite studies. In: Henry DO, Beaver JE (eds) The sands of time: the desert Neolithic settlement at Ayn Abū Nukhayla. Bibliotheca neolithica Asiae meridionalis et occidentalis. Ex oriente, Berlin, pp 121-137

Portillo M, Albert RM (2014b) Microfossil evidence for grinding activities. Revista d'Arqueologia de Ponent 24:103-112

Portillo M, Albert RM, Henry DO (2009) Domestic activities and spatial distribution in Ain Abu Nukhayla (Wadi Rum, Southern Jordan): The use of phytoliths and spherulites studies. Quat Int 193:174-183. doi:10.1016/j.quaint.2007.06.002

Portillo M, Bofill M, Molist M, Albert RM (2013) Phytolith and use-wear functional evidence for grinding stones from the Near East. In: Anderson PC, Cheval C, Durand A (eds) Regards croisés sur les outils liés au travail des végétaux. An interdisciplinary focus on plant working tools. APDCA, Antibes, pp 161-174

Portillo M, Kadowaki S, Nishiaki Y, Albert RM (2014a) Early Neolithic household behavior at Tell Seker alAheimar (Upper Khabur, Syria): a comparison to ethnoarchaeological study of phytoliths and dung spherulites. J Archaeol Sci 42:107-118. doi:10.1016/j.jas.2013.10.038

Portillo M, Llergo Y, Ferrer A, Anglada M, Plantalamor L, Albert RM (2014b) Actividades domésticas y molienda en el asentamiento talayótico de Cornia Nou (Menorca, Islas Baleares): resultados del estudio de microfósiles vegetales. Revista d'Arqueologia de Ponent 24:311-321

Power RC, Rosen AM, Nadel D (2014) The economic and ritual utilization of plants at the Raqefet Cave Natufian site: The evidence from phytoliths. J Anthropol Archaeol 33:49-65. doi:10.1016/j.jaa.2013.11.002

Procopiou H (2003) Les techniques de décorticage dans le monde égéen. Étude ethnoarchéologique dans les Cyclades. In: Anderson PC, Cummings LS, Schippers TK, Simonel B (eds) Le traitement des récoltes: un regard sur la diversité, du Néolithique au présent. APDCA, Antibes, pp 115-136 
Radomski KU, Neumann K (2011) Grasses and grinding stones: inflorescence phytoliths from modern West African Poaceae and archaeological stone artefacts. In: Fahmy AG, Kahlheber S, D'Andrea AC (eds) Windows on the African past. Current approaches to African archaeobotany. Africa Magna Verlag, Frankfurt, pp 153-166

Raviele ME (2011) Experimental assessment of maize phytolith and starch taphonomy in carbonized cooking residues. J Archaeol Sci 38:2,708-2,713. doi:10.1016/j.jas.2011.06.008

Red Balear de Aeropalinología (2015) Menorca pollen calendar. http://www.caib.es. Accessed 2 June 2015

Reille M (1992) Pollen et spores d'Europe et d'Afrique du Nord. URA CNRS 1152. Laboratoire de Botanique Historique et Palynologie, Marseille

Reille M (1995) Pollen et spores d'Europe et d'Afrique du Nord (Supplément 1). URA CNRS 1152. Laboratoire de Botanique Historique et Palynologie, Marseille

Reille M (1998) Pollen et spores d'Europe et d'Afrique du Nord (Supplément 2). URA CNRS 1152. Laboratoire de Botanique Historique et Palynologie, Marseille

Risch R (2003) Los artefactos macrolíticos del yacimiento del Puig Morter de Son Ferragut. In: CastroMartínez PV, Escoriza-Mateu M, Sanahuja-YII E (eds) Mujeres y hombres en espacios domésticos: trabajo y vida social en la prehistoria de Mallorca (c. 700-500 cal ANE). El Edificio Alta del Puig Morter de Son Ferragut (Sineu, Mallorca). Archaeopress, Oxford, pp 306-319

Rosen AM (1992) Preliminary identification of silica skeletons from Near Eastern archaeological sites: an anatomical approach. In: Rapp JrG, Mulholland SC (eds) Phytolith systematics: emerging issues, advances in archaeological and museum science. Plenum Press, New York, pp 129-147

Shillito LM (2011) Taphonomic observations of archaeological wheat phytoliths from Neolithic Çatalhöyük, Turkey, and the use of conjoined phytolith size as an indicator of water availability. Archaeometry 53:631641. doi: 10.1111/j.1475-4754.2010.00582.x

Stika HP (1999) Los macrorrestos botánicos de la Cova d'es Càrritx. In: Lull V, Micó R, Rihuete C, Risch R (eds) Ideología y sociedad en la prehistoria de Menorca. La Cova des Càrritx y la Cova des Mussol. Consell Insular de Menorca, Maó, pp 521-532

Stockmar J (1971) Tablets with spores used in absolute pollen analysis. Pollen et spores 13:615-621

Subba Reddi C, Reddi NS (1986) Pollen production in some anemophilous angiosperms. Grana 25:55-61

Terradas X, Ibanez JJ, Braemer F, Hardy K, Iriarte E, Madella M, Ortega D, Radini A, Teira LC (2013) Natufian bedrock mortars at Qarassa 3: preliminary results from an interdisciplinary methodology. In: Borrell F, Ibáñez JJ, Molist M (eds) Stone tools in transition: from hunter-gatherers to farming societies in the Near East. Universitat Autònoma de Barcelona, Servei de Publicacions, Barcelona, pp 441-456

Tsartsidou G, Lev-Yadun S, Albert RM, Miller-Rosen A, Efstratiou N, Weiner S (2007) The phytolith archaeological record: strengths and weaknesses based on a quantitative modern reference collection from Greece. J Archaeol Sci 34:1,262-1,275. doi:10.1016/j.jas.2006.10.017

Twiss PC (1992) Predicted world distribution of $\mathrm{C}_{3}$ and $\mathrm{C}_{4}$ grass phytoliths. In: Rapp JrG, Mulholland SC (eds) Phytolith systematics: emerging issues, advances in archaeological and museum science. Plenum Press, New York, pp 113-128

Twiss PC, Suess E, Smith RM (1969) Morphological classification of grass phytoliths. Soil Sci Soc Am Proc 33:109-115 
Valamoti SM (2002) Food remains from Bronze Age Archondiko and Mesimeriani Toumba in northern Greece? Veget Hist Archaeobot 11:17-22

Vicent JM, Rodríguez Alcalde AL, López Sáez JA, De Zavala Morencos I, López García P, Martínez Navarrete MI (2000) ¿Catástrofes ecológicas en la estepa? Arqueología del Paisaje en el complejo minerometalúrgico de Kargaly (Región de Orenburg, Rusia). Trabajos de Prehistoria 57:29-74. doi:10.3989/tp.2000.v57.i1.260

Vuorela I (1973) Relative pollen rain around cultivated fields. Acta Botanica Fennica 102:1-27

Willcox G, Stordeur D (2012) Large-scale cereal processing before domestication during the tenth millennium cal BC in northern Syria. Antiquity 86:99-114. doi:10.1017/S0003598X00062487

Wright KL (1991) The origins and development of ground stone assemblages in Late Pleistocene Southwest Asia. Paléorient 17:19-45. doi:10.3406/paleo.1991.4537

Wright KL (1994) Ground stone tools and hunter-gatherer subsistence in southwest Asia: implications for the transition to farming. Am Antiqu 59:238-263. doi:10.2307/281929 


\section{Figures}

Fig. 1 top, location of Mallorca and Menorca (Balearic Islands, Spain), where the Talayotic culture is known; bottom, localities in Menorca cited in the text. 1, pollen count station at Alaior; 2, barley field at Algendaret; 3, Cornia Nou Talayotic settlement site, Mahon; 4, Museum of Menorca, Mahon

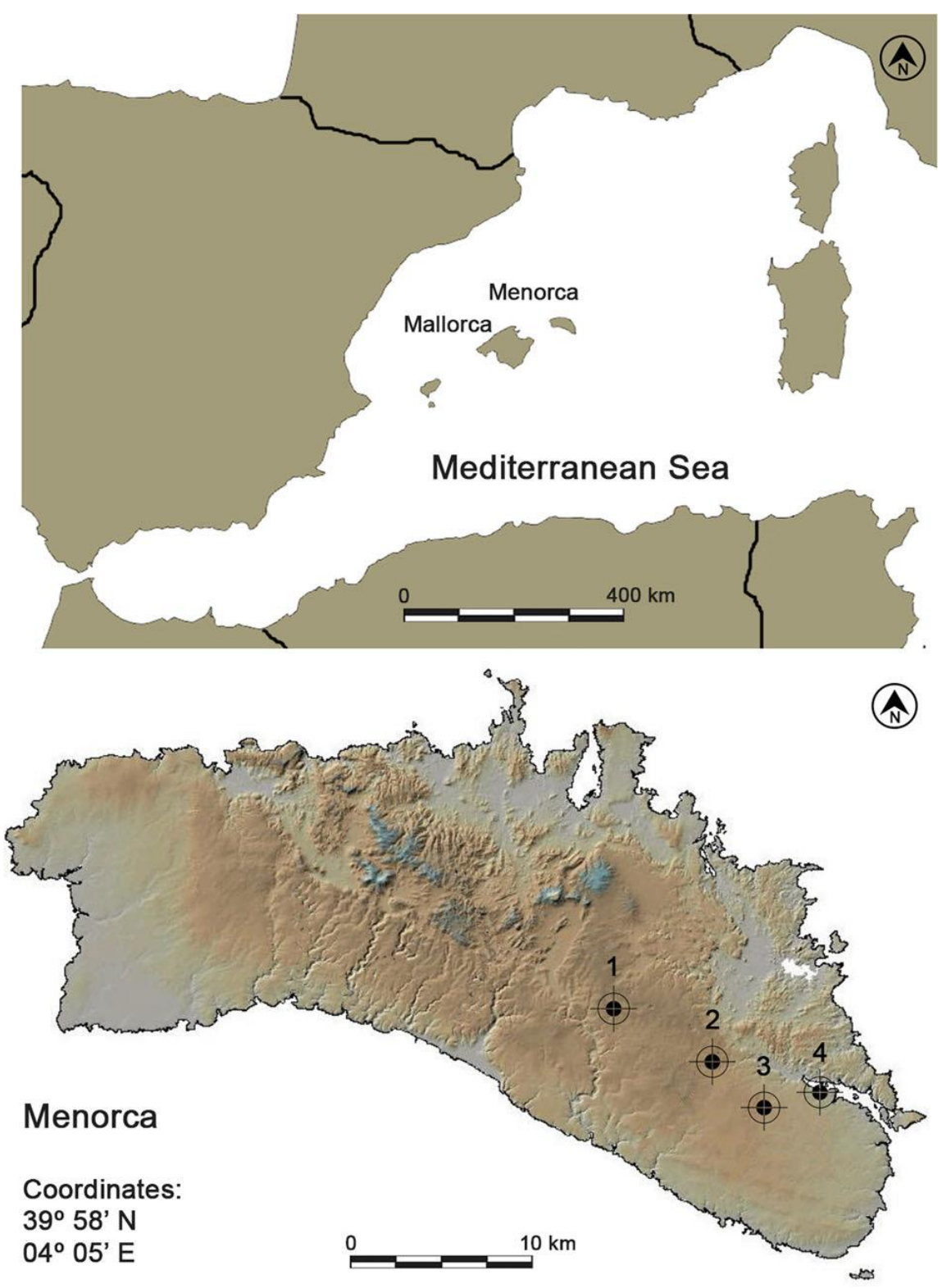


Fig. 2 Processing stages of experimental work in Menorca, early June-July 2011. a, description of processing techniques and place; $\mathbf{b}$, winnowing with a sieve; $\mathbf{c}$, active surface of the mortar after dehusking; d, grinding; e, sieving the flour

\section{a PROCESSING STAGES}

\section{HARVESTING}

Mature cereal reaped by hand using an iron sickle, Algendaret Nou (SE Menorca, beginning of June)

\section{STORAGE}

Storage of whole plants at the museum, Mahon

(indoors, until the end of July)

\section{THRESHING-WINNOWING-SIEVING}

Rubbing plucked ears and beating whole plants. Winnowed with a $3 \mathrm{~mm}$ sieve, followed by a second sieving $(1 \mathrm{~mm})$ (outdoors, end of July)

\section{DEHUSKING-SIEVING}

Hulled grain processed with a Talayotic mortar and beaten with a wooden pestle. Sieved ( $1 \mathrm{~mm}$ mesh size) and operation repeated until the grain becomes clean (outdoors)

\section{GRINDING}

Clean grain processed with Talayotic grinding stones, with a back-and-forth movement combined with a partial rotating motion (indoors)

\section{SIEVING}

Grinding product sieved with a metal mesh $(0.5 \mathrm{~mm})$ to remove undesired particles from the final product, the flour
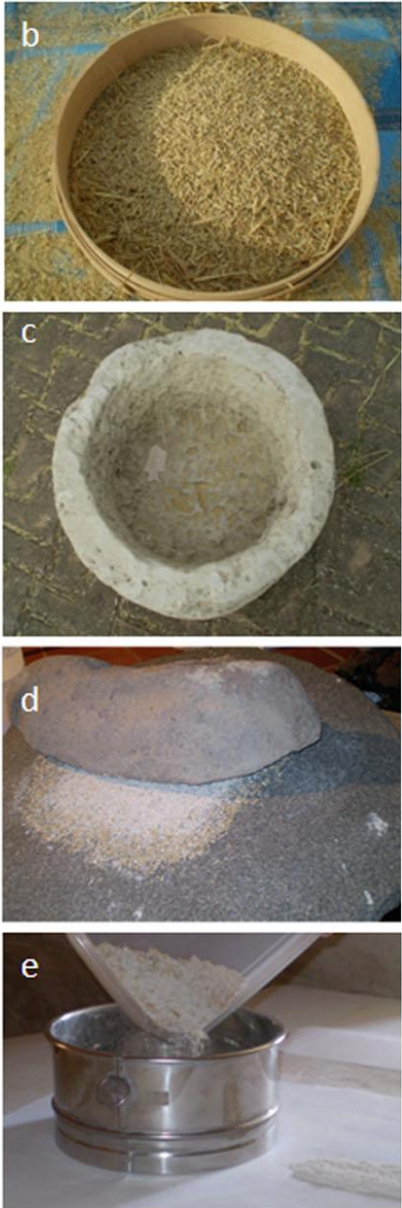
Fig. 3 Hordeum vulgare multicellular phytoliths $(\mathrm{MC}) \times 400$. Unprocessed plant parts $(\mathrm{a}, \mathrm{b}, \mathrm{c})$ compared with experimental samples (d,e,f). a, sample PHYH-3, MC of dendritic long cells with papillae and short cells, from inflorescences; b, sample PHY-4, MC with stomata cells, from stems; c, sample PHY-5, MC with short cells from leaves; d, sample PHY-8, MC with short cells from leaves/stems (mortar working surface); e, sample PHY-10, MC of dendritic long cells with papillae from husks (quern grinding surface); f, sample PHY-12, MC of dendritic long cells with papillae from husks (sieved grinding by-product)
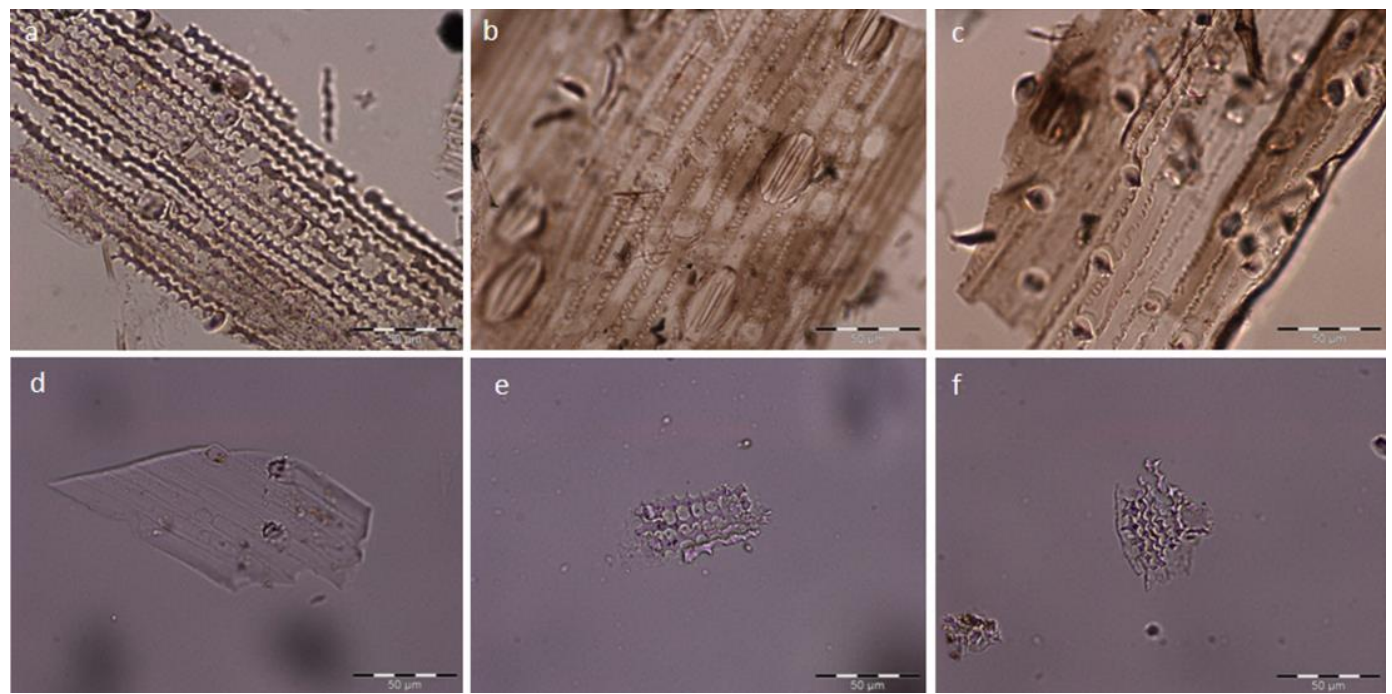

Fig. 4 Phytolith size ranges from selected samples expressed as numbers of cells included in multicellular phytoliths. Note the increase of the smallest size group with 3-10 cells within multicells. a, sample PHYH-3, inflorescence (unprocessed), number of individual cells counted n = 5543; b, sample PHYH-8, mortar working surface, $\mathrm{n}=668$; , sample PHYH-10, quern grinding surface, $n=367$. For references to colour in this figure legend, readers are referred to the web version of this article
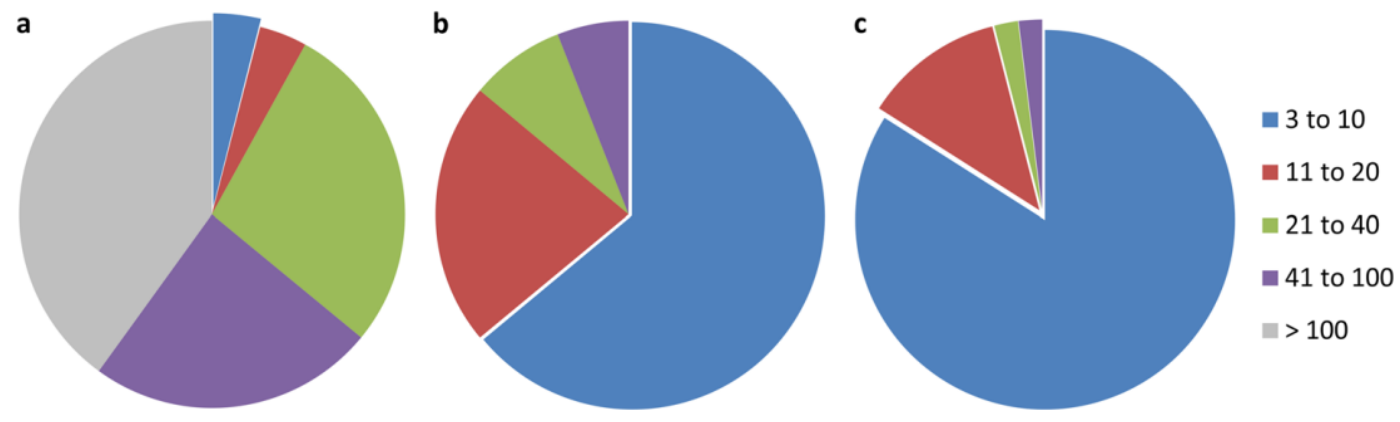


\section{Tables}

Table 1 Description of samples and processing techniques for phytolith (PHY) and pollen (PO) samples

\begin{tabular}{|c|c|c|}
\hline $\begin{array}{l}\text { Phytolith } \\
\text { sample no. }\end{array}$ & $\begin{array}{l}\text { Pollen } \\
\text { sample no. }\end{array}$ & Part of the plant, description of processing technique \\
\hline 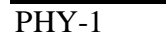 & & Sediment from the field (after harvesting) \\
\hline PHY-2 & PO-1 & Whole plant (unprocessed) \\
\hline PHY-3 & PO-2 & Inflorescence (unprocessed) \\
\hline PHY-4 & PO-3 & Stem (unprocessed) \\
\hline PHY-5 & PO-4 & Leaves (unprocessed) \\
\hline PHY-6 & & $\begin{array}{l}\text { Dehusking mortar content sampled by dry brushing: complete cereal and weed } \\
\text { grains, fragmented naked or hulled grains and small bract fragments }\end{array}$ \\
\hline \multirow[t]{2}{*}{ PHY-7 } & PO-5 & $\begin{array}{l}\text { Sieving }(\geq 1 \mathrm{~mm}) \text { and winnowing by-product: spikelet and large bract fragments } \\
\text { from pounding, light chaff and weeds }\end{array}$ \\
\hline & PO-6 & Clean hulled grains after sieving and winnowing \\
\hline \multirow[t]{2}{*}{ PHY-8 } & & $\begin{array}{l}\text { Mortar working surface sampled by washing: small cereal and weed grain } \\
\text { fragments, bract fragments and light chaff }\end{array}$ \\
\hline & PO-7 & $\begin{array}{l}\text { Mortar working surface, dry brushing: small cereal and weed seed fragments, bract } \\
\text { fragments and light chaff }\end{array}$ \\
\hline PHY-9 & PO-8 & $\begin{array}{l}\text { Grinding quern surface, dry brushing: small grain fragments, small bract fragments } \\
\text { and flour }\end{array}$ \\
\hline PHY-10 & & Grinding quern surface, washed: fine grain and bract fragments and flour \\
\hline PHY-11 & PO-9 & $\begin{array}{l}\text { Sieved grinding by-product }(\geq 0.5 \mathrm{~mm}) \text { : small husk, grain and small weed } \\
\text { fragments }\end{array}$ \\
\hline PHY-12 & PO-10 & Sieved fine flour $(\leq 0.5 \mathrm{~mm})$ \\
\hline
\end{tabular}

Table 2 Main quantitative phytolith results

\begin{tabular}{|c|c|c|c|c|}
\hline Sample no. & $\begin{array}{l}\text { N. phytoliths } \\
1 \quad \text { g } \quad \text { sediment/ } \\
\text { dried material }\end{array}$ & $\begin{array}{l}\text { Phytoliths } \\
\text { weathering } \\
(\%)\end{array}$ & $\begin{array}{l}\text { Multicelled } \\
\text { Phytoliths } \\
(\%)\end{array}$ & $\begin{array}{l}\text { Ratio individual/ } \\
\text { multicelled } \\
\text { phytoliths }\end{array}$ \\
\hline PHY-1 & 40.000 & 8.8 & 1.1 & 0.01 \\
\hline PHY-2 & 2.100 .000 & 4.6 & 26.9 & 0.39 \\
\hline PHY-3 & 1.100 .000 & 2.2 & 45.9 & 0.88 \\
\hline PHY-4 & 1.000 .000 & 7.3 & 57.8 & 1.65 \\
\hline PHY-5 & 1.000 .000 & 5 & 41.9 & 0.79 \\
\hline PHY-6 & 2.600 .000 & 3 & 38.4 & 0.66 \\
\hline PHY-7 & 1.700 .000 & 3.5 & 39 & 0.68 \\
\hline PHY-8 & 1.300 .000 & 2.1 & 35 & 0.56 \\
\hline PHY-9 & 800.000 & 4.8 & 36 & 0.61 \\
\hline PHY-10 & 120.000 & 7.4 & 31.1 & 0.51 \\
\hline PHY-11 & 500.000 & 5 & 32.6 & 0.52 \\
\hline PHY-12 & 1.000 .000 & 15 & 23.3 & 0.33 \\
\hline
\end{tabular}


Table 3 Main pollen results. Concentrations are expressed in numbers of pollen grains/g dry plant material and relative percentages of main pollen types $(*=$ below $1.5 \%)$

\begin{tabular}{|c|c|c|c|c|}
\hline $\begin{array}{l}\text { Sample } \\
\text { no. }\end{array}$ & $\begin{array}{l}\text { Total pollen } \\
\text { conc. } \\
\text { (grains/g) }\end{array}$ & $\begin{array}{l}\text { Cereal pollen } \\
\text { con. } \\
\text { (grains/g) }\end{array}$ & $\begin{array}{l}\text { Cereal } \\
\text { pollen } \\
(\%)\end{array}$ & Other pollen types identified \\
\hline PO-1 & 24.500 & 4.700 & 19.2 & $\begin{array}{l}\text { Poaceae, Olea, Asteroideae, Quercus, Pinus, } \\
\text { Plantago }(*), \text { Rumex, Fabaceae, Cichorioideae }(*), \\
\text { Chenopodiaceae }(*) \text {, Apiaceae }(*)\end{array}$ \\
\hline PO-2 & 12.500 & 4.500 & 35.7 & $\begin{array}{l}\text { Poaceae, Olea, Quercus, Pinus, Plantago(*), } \\
\text { Asteroideae, Cichorioideae (*), Rumex }\end{array}$ \\
\hline PO-3 & 11.500 & 1.000 & 11.7 & Olea, Poaceae, Asteroideae, Quercus, Pinus \\
\hline PO-4 & 182.000 & 20.500 & 11.2 & $\begin{array}{l}\text { Poaceae, Olea, Fabaceae, Asteroideae, Pinus, } \\
\text { Plantago }(*), \text { Chenopodiaceae }(*), \text { Rumex, Quercus, } \\
\text { Cichorioidea }(*)\end{array}$ \\
\hline PO-5 & 66.500 & 23.000 & 34.6 & $\begin{array}{l}\text { Poaceae, Olea, Rumex, Pinus, Quercus, } \\
\text { Plantago }(*), \text { Chenopodiaceae }(*), \\
\text { Cichorioideae }(*), \text { Asteroideae, Fabaceae, } \\
\text { Apiaceae }(*)\end{array}$ \\
\hline PO-6 & 3.800 & 1.200 & 30.1 & Poaceae, Olea, Quercus, Rumex, Pinus \\
\hline PO-7 & 195.000 & 145.000 & 76.4 & $\begin{array}{l}\text { Poaceae, Olea, Apiaceae }(*) \text {, Asteroideae, Rumex, } \\
\text { Quercus, Pinus, Plantago( }(*) \text {, Cichorioideae }(*)\end{array}$ \\
\hline PO-8 & 10.600 & 4.000 & 36.8 & Poaceae, Pinus, Quercus \\
\hline PO-9 & 1.800 & 1.500 & 79.2 & $\begin{array}{l}\text { Poaceae, Olea, Quercus, Rumex, Plantago (*), } \\
\text { Apiaceae(*), Pinus }\end{array}$ \\
\hline PO-10 & 15.300 & 13.000 & 85.5 & $\begin{array}{l}\text { Poaceae, Olea, Asteroideae, Quercus, Plantago }(*) \text {, } \\
\text { Apiaceae }(*), \text { Pinus }\end{array}$ \\
\hline
\end{tabular}


Table 4 Main phytolith morphologies from samples and their correspondence to the ICPN morphotypes (Madella et al. 2005). B= Bulliform cell (ICPN Cuneiform and parallepipedal bulliform cell), EA $\mathrm{H}=$ Epidermal appendage hair (hair cell), EA PA= Epidermal appendage papillae (papillae cell), EA PR= Epidermal appendage prickle (prickle), LCD= Long cell dendritic (dendritic), LCE = Long cell echinate (elongate echinate long cell), MC LCD= Multicellular structure of dendritic long cells (silica skeleton with dendritic cells/ with papillae/ short cells), MC LCE $=$ Multicellular structure of echinate long cells (silica skeleton with echinate cells/ with papillae/ short cells), $\mathrm{SHC}=\mathrm{Short}$ cell (rondel short cell/ trapeziform short cell), $\mathrm{S}=\mathrm{Stomata}$ (stomate)

\begin{tabular}{lllllllllll}
\hline $\begin{array}{l}\text { Sample } \\
\text { no. }\end{array}$ & $\%$ B & \% EA H & $\begin{array}{l}\text { \% EA } \\
\text { PA }\end{array}$ & $\begin{array}{l}\text { \% EA } \\
\text { PR }\end{array}$ & $\begin{array}{c}\text { \% LCD } \\
\text { \% LCE }\end{array}$ & $\begin{array}{c}\text { \% MC } \\
\text { LCD }\end{array}$ & $\begin{array}{l}\text { \% MC } \\
\text { LCE }\end{array}$ & \% SHC & \% S \\
\hline PHY-1 & 3.3 & 0.6 & 0.6 & 6.1 & 0.6 & 3.3 & 0 & 0 & 17.7 & 0 \\
PHY-2 & 0 & 3.1 & 3.7 & 0.3 & 5.5 & 6.1 & 4.3 & 7 & 22.3 & 3.1 \\
PHY-3 & 0 & 6.9 & 2.9 & 0 & 12.9 & 17.9 & 13.2 & 11 & 4.1 & 0 \\
PHY-4 & 0.7 & 1 & 0 & 0 & 0.3 & 0.7 & 8.3 & 19.4 & 4.5 & 0.7 \\
PHY-5 & 0.2 & 1.4 & 0.2 & 1.4 & 0 & 0 & 2.2 & 9.3 & 26.3 & 9.1 \\
PHY-6 & 0 & 19.5 & 2.7 & 0.3 & 3 & 12.8 & 4 & 13.5 & 6.7 & 0.3 \\
PHY-7 & 0 & 16.9 & 0.8 & 1.2 & 0.8 & 7.5 & 2.8 & 16.1 & 4.3 & 0 \\
PHY-8 & 0 & 32.5 & 0 & 1.3 & 0 & 0.8 & 0 & 1.3 & 0.4 & 0.8 \\
PHY-9 & 0 & 2.2 & 4.8 & 0 & 5.9 & 30.9 & 11.8 & 15.4 & 9.2 & 0.4 \\
PHY-10 & 0 & 0.7 & 0.7 & 0 & 2.7 & 41.2 & 2 & 20.9 & 5.4 & 0 \\
PHY-11 & 0.7 & 6.8 & 4.7 & 0.4 & 3.6 & 21.5 & 6.1 & 18.6 & 14.7 & 0 \\
PHY-12 & 0 & 3.5 & 4.6 & 0 & 0.7 & 28.6 & 1.4 & 13.4 & 17.3 & 0 \\
\hline
\end{tabular}


Table 5 Size ranges and counts obtained from anatomically connected phytoliths of hulled Hordeum vulagare ( $n$ min=50 multicells, except sediment sample PHY-1)

\begin{tabular}{|c|c|c|c|c|c|}
\hline \multicolumn{3}{|c|}{ Hulled barley (Hordeum vulgare) } & \multicolumn{3}{|l|}{ Size range } \\
\hline $\begin{array}{l}\text { Sample } \\
\text { no. }\end{array}$ & $\begin{array}{l}\text { Sample type- } \\
\text { processing stage }\end{array}$ & $\begin{array}{l}\text { N. individual } \\
\text { cells counted }\end{array}$ & N. min cells & N. max cells & $\begin{array}{l}\text { Average } \mathbf{N} \text {. } \\
\text { cells }\end{array}$ \\
\hline PHY-1 & Sediment (harvesting) & 19 & 3 & 6 & 0.38 \\
\hline PHY-2 & $\begin{array}{l}\text { Whole plant (non- } \\
\text { processed) }\end{array}$ & 4819 & 6 & 430 & 96.38 \\
\hline PHY-3 & $\begin{array}{l}\text { Inflorescence (non- } \\
\text { processed) }\end{array}$ & 5543 & 5 & 632 & 110.86 \\
\hline PHY-4 & Stem (non-processed) & 3177 & 4 & 573 & 63.54 \\
\hline PHY-5 & Leaves (non-processed) & 1607 & 6 & 143 & 32.14 \\
\hline PHY-6 & Dehusking & 1515 & 4 & 128 & 30.3 \\
\hline PHY-7 & Dehusking - sieving & 2966 & 4 & 499 & 59.32 \\
\hline PHY-8 & Dehusking & 668 & 3 & 77 & 13.36 \\
\hline PHY-9 & Grinding & 1124 & 3 & 82 & 22.48 \\
\hline PHY-10 & Grinding & 367 & 3 & 46 & 7.34 \\
\hline PHY-11 & Grinding & 919 & 3 & 103 & 18.38 \\
\hline PHY-12 & Grinding - sieving & 326 & 3 & 39 & 6.52 \\
\hline
\end{tabular}




\section{Electronic supplementary material}

ESM Fig. 1 Ground stone tools used in the experimental work. a, pestle, pinewood; b, mortar, limestone; c, handstone, Triassic sandstone; d, quern, Triassic microconglomerate. These Talayotic stone tools, of unknown archaeological context, are in the Museum of Menorca

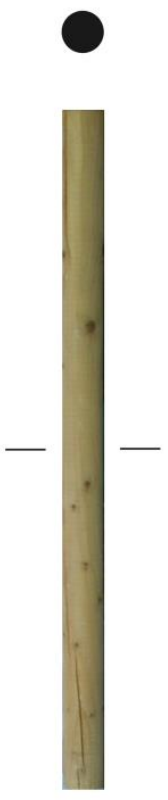

a

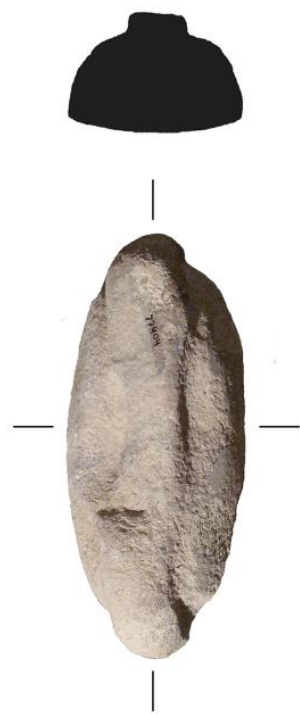

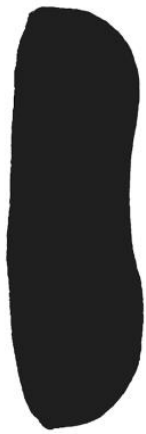

C
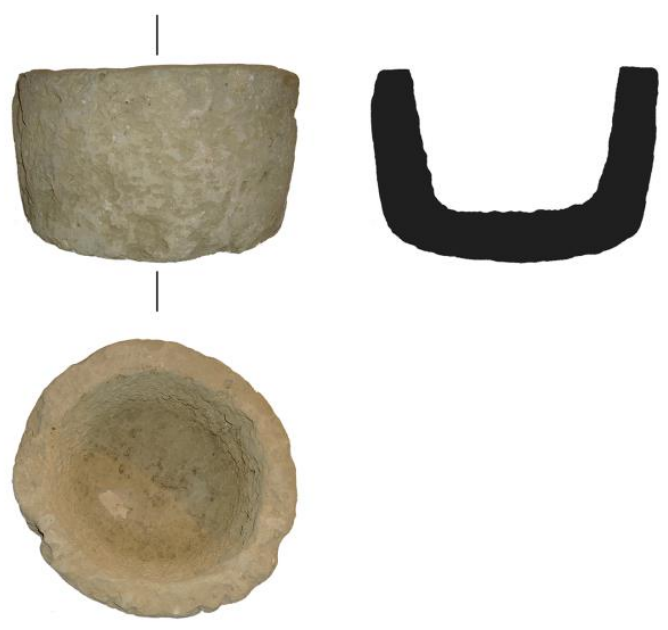

b

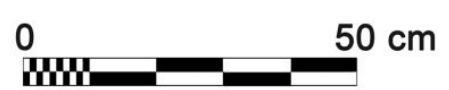


ESM Fig. 2 Hordeum vulgare (barley), cultivated on the island at present. a, Algendaret Nou, southeastern Menorca, June 2011; b, mature cereal

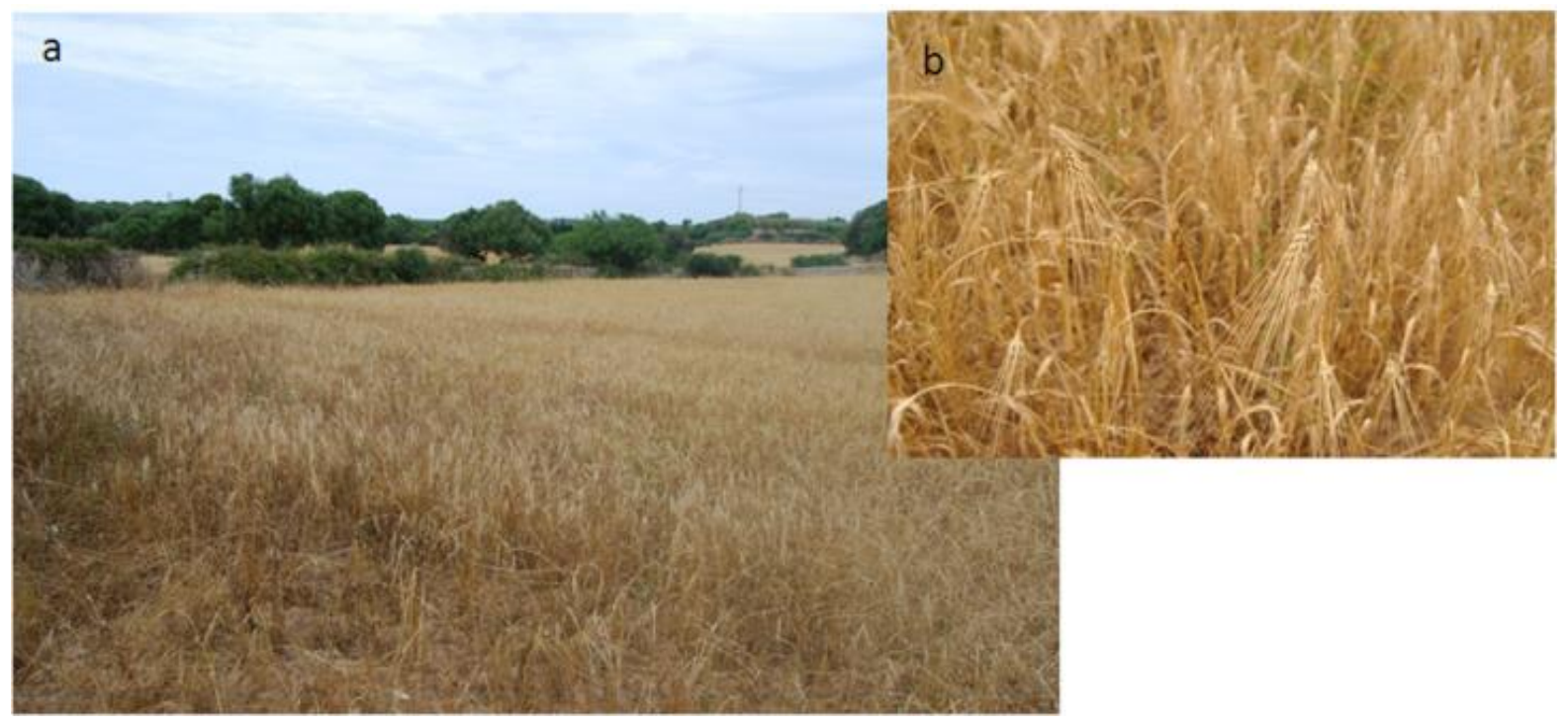

ESM Fig. 3 a, cereal pollen distribution from unprocessed part plants, expressed in number of pollen grains/g dry plant material; b,c, Hordeum vulgare pollen grains

a

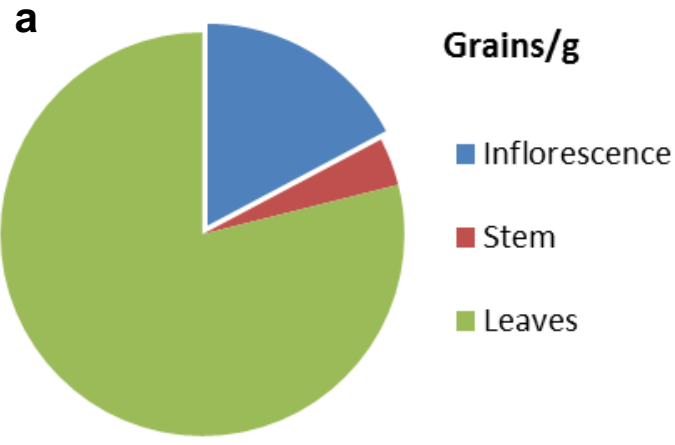

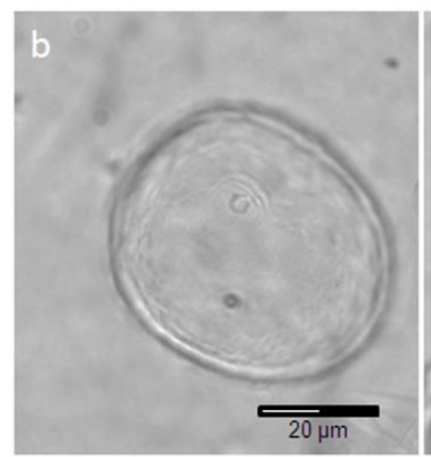

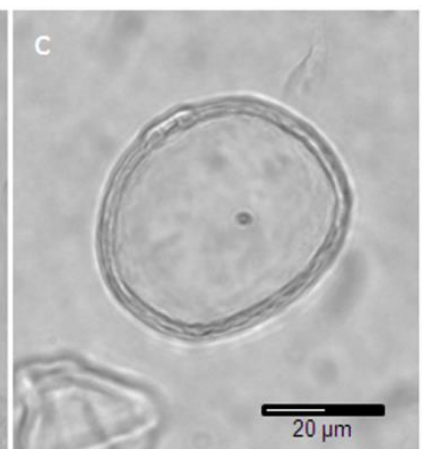

